\title{
International Report
}

Marilyn Naidoo

\section{Ministerial Formation and Practical Theology in South Africa}

DOI 10.1515/ijpt-2015-0004

\begin{abstract}
The time of theological training is crucial for ministers to encourage a mature development of occupational and personal identity and foster a coherent understanding of their role and function in ministry. Ministerial formation must involve training and equipping of pastoral leaders to do theology by involvement on a grassroots level and developing responsiveness to historical, biblical and pastoral dimensions within its context in order to have relevance. The article will map the South African scene in terms of ministerial formation, highlighting recent higher education changes with a discussion on ministerial formation within academic Practical theology in universities and conclude with wider contextual and research needs.
\end{abstract}

Zusammenfassung: Die Zeit der theologischen Ausbildung von Pfarrern ist entscheidend für die Entwicklung ihrer beruflichen und persönlichen Identität sowie eines kohärenten Verständnisses ihrer Rolle und Funktion im Pfarramt. Die Pfarrausbildung muss pastorale Führungskräfte hervorbringen, die Theologie auf einer basisnahen Ebene und unter der Ausbildung eines Bewusstseins für die historische, biblische und pastorale Dimension im jeweiligen Kontext ausüben können. Dieser Artikel stellt die südafrikanischen Gegebenheiten in Bezug auf die Pfarrausbildung dar. Dabei werden die jüngsten Entwicklungen der Hochschulausbildung hervorgehoben und die Pfarrausbildung innerhalb der akademischen Praktischen Theologie an Universitäten diskutiert. Abschließend werden Forschungsdesiderate und kontextuelle Besonderheiten aufgezeigt.

\section{Introduction}

Theological education and ministerial formation have been in a state of flux and uncertainty globally for a number of years. This has been precipitated by the impact

Prof. Dr. Marilyn Naidoo: University of South Africa, Philosophy, Systematic \& Practical Theology, PO Box 392 Unisarand Pretoria Gauteng 0003, South Africa, Email: naidom2@unisa.ac.za 
of globalisation on theological education, the process of rationalisation within educational and ecclesiastical institutions, the competing and sometimes adversarial interests of liberal, radical and conservative theological establishments and the crisis in the vocation with regard to the ordained and lay ministry within the Church. ${ }^{1}$ Post-apartheid South Africa with its rapid economic and social change has felt the impact of the above changes and theological education has already faced significant developments. The Church in South Africa faces the task of reconstructing its congregational life, its educational institutions and its witness in the world in the midst of an increasingly globalised society, where people's desires are often more shaped by consumer culture than by the grace of God, where convictions are more often shaped by state power than by the cross, and where activities are often more shaped by habits of division and violence rather than reconciliation. Even though an impressive infrastructure for theological education exists, compared to the rest of Africa - with about 9 public universities and 20 denominational seminaries offering accredited theological education, 15 professional theological societies and 20 accredited theological journals - it is still a context full of contradictions especially at the level of race, class and gender.

In a country where people are deeply religious with a significant percentage of Christians, ${ }^{2}$ the focus of religious or ministerial formation is strategically important as religion plays a critical role in supporting human rights, democracy and development. ${ }^{3}$ South African churches today are interacting with a democratic state that respects religious pluralism rather than a once authoritarian state that upheld Christian nationalism. In doing so, churches are trying to make sense of their new role in terms of culture, political profile and social influence, as social and cultural systems that once held religious identity and traditions fragment. These changes include new "leadership patterns, the new dominance of forms of Christianity not bound to the original mission churches, the confusion of identity and purpose in the ecumenically-aligned churches and a shifting local social imaginary." ${ }^{4}$ To make sense of its changing role, the Church remains heavily dependent upon its ordained ministers for the vision and inspiration

1 Cf. Desmond P. Van der Water, Transforming Theological Education and Ministerial Formation, International Review of Mission, 94/373, 2005, 203-211.

2 In the 2001 census it was found that $79.8 \%$ were Christian, 15\% no religion, 1.5\% Islam, $1.2 \%$ Hinduism $0.3 \%$, African traditional belief $0.2 \%$, Judaism $0.6 \%$ and other beliefs, with about $1.4 \%$ undecided. $40.9 \%$ of Christians belonged to a mainline church (Anglican, Methodist, Presbyterian, Lutheran, Reformed, Roman Catholic, Orthodox and Congregational churches) while 47.2\% belong to independent Charismatic/Pentecostal churches, the majority to the African Independent Churches. See Statistics South Africa 2001 (www.statssa.gov.za, last viewed April 08, 2015).

3 Cf. Tracy Kuperus, The Political Role and Democratic Contribution of Churches in Post-Apartheid South Africa, in: Journal of Church and State 53/2, 2011, 278-306. 
which are to motivate both its worship and mission. At the same time there is an acknowledgement that a new paradigm is needed for doing theology, and a new kind of Christian leadership is needed that is able to lead churches towards meaningful engagement in society. Ministers arrive at an understanding of their role through the complex interrelationship of responses from peer group influence, congregational, community and institutional role expectancy and professional training. The influence of the training experience is a key factor in determining role understanding and ministerial practice, effectiveness and "success." Thus the character, activities and teaching of ministerial candidates are important to reflect on, so as to re-consider how to better 'form' pastoral leaders who can create, renovate, sustain and extend religious institutions.

In recent years practical theology has re-emerged as a unifying focus in theological discussion and theological education. As we know, theology in any 'classical' period in its history has been the product of the Church's construction and innovation in Christian presence in church and society. Work in practical theology seeks to return to the dialectic between the Church's normative memory and vision and its struggle toward the action of Christian discipleship in the world. ${ }^{5}$ While all Christians may be involved in "doing theology," very few have the opportunity to engage formally in "studying theology" which is by definition done at theological institutions. Practical theology in South Africa is very much concerned with pastoral action, church life and training for ministry ${ }^{6}$ focused on contextual theology and working towards growing involvement in public issues. In a country where the Church has a substantive role, theological students, as pastors and lay leaders turn to practical theology for insight into the task of being contextually relevant. Ministerial formation in this context is challenged by the assumption that theological institutions in South Africa ought to be shaping and forming church leaders who can serve the almost insurmountable social needs of our country, be visionary with moral integrity and be able to attend with competence to the many pastoral tasks at a local church level. On the other hand, theological institutions must determine how to take on the difficult task of forming leaders with fewer resources within the changing landscape of higher education in South Africa. In the middle of these well-intended struggles rests a central

4 James R. Cochrane, Circles of Dignity. Community Wisdom and Theological Reflection, Minneapolis (Fortress Press) 1999, $95 \mathrm{f}$.

5 Cf. James W. Fowler, Practical Theology and Theological Education. Some Models and Questions, in: Theology Today 42/1, 1985, $54 \mathrm{f}$.

6 Jaco S. Dreyer, Practical Theology in South Africa, in: Bonnie J. Miller-McLemore (ed.), The Wiley-Blackwell Companion to Practical Theology, Oxford (Wiley-Blackwell) 2012, 505-514, $511 \mathrm{f}$. 
question about the purpose and meaning of ministerial formation and its relevance to the context.

As the formational mandate becomes more a part of theological training, it is imperative to develop a more nuanced discussion regarding the relationship of ministerial formation to practical theology in this context. Formation takes place in three distinct but overlapping settings, that is, in formal education, in congregational life and in situations of social engagement. It is important to note the interconnectedness and that each area is largely impacted by the other dimensions. In this article the focus will be ministerial formation in theological institutions, primarily the universities as in this context they are viewed as the thoughtleaders, which seminaries follow. The intent of this article is to map out the South African scene in terms of ministerial formation, highlighting recent higher education changes with a discussion on ministerial formation within academic practical theology in universities, concluding with a discussion on broader contextual and research challenges.

\section{Changing Landscape of Theological Education}

One may say that theological education in South Africa reflects the deep divides of the context within which it is situated - as we know South Africa is politically, economically and culturally a contested space and theological education is equally complex and heterogeneous. ${ }^{7}$ Currently the spectrum of offerings includes university faculties of theology serving particular denominations or that are ecumenical, university departments of religious studies, accredited denominational/interdenominational Bible schools and seminaries, unaccredited Bible schools, apprenticeships, short-term courses offered by well-meaning global partners, outright sale of certificates, moving courseware across borders and a host of other strategies. Also, in spite of the widening digital-divide in South Africa, there has been a surge of interest in new technologies that has caused an eager population to become further connected, though still to varying degrees. Many theological institutions have now moved into distance (correspondence) education, seen as a solution to the financial viability of institutions. The rich history of denominational theological education in South Africa, ${ }^{8}$ together with higher education

7 Cf. Ernst Conradie, Is the re-integration of theological education viable?, in: Marilyn Naidoo (ed.), Contested Issues in Training Ministers in South Africa, Stellenbosch (Sun Media) 2015, 24-37.

8 Cf. Marilyn Naidoo, Between the Real and the Ideal. Ministerial Formation in South African churches, Pretoria (Unisa Press) 2012. 
changes, need to be understood to show how the ministerial training is currently shaped and takes place.

Firstly, it is important to note four distinctive eras of theological education ${ }^{9}$ and to recognise the changing cultural and political contexts within which the successive eras developed in South Africa. The first (1867-1948) was the missionary era characterised by two main interfaces, that of Western Christianity and Africa, and the interface of power between British colonial authority and the loss of African autonomy. The second era (1948-1990) saw the imposition of the notoriously oppressive political system known as apartheid. Overlapping with apartheid was the third era (1960-1990), that of resistance against apartheid particularly in the case of the churches that participated in ecumenical initiatives and structures such as the South Africa Council of Churches. Finally, there is the post-apartheid era (1994 to the present) in which the churches are trying to make sense of their new role in terms of culture, political profile and social influence.

Higher education systems have previously been characterised by fragmentation, uneven provision and decades of racial segregation. The challenge of higher education transformation co-existed with demands for social and economic justice. $^{10}$ Due to this restructuring of higher education over the past decade, ${ }^{11}$ theological faculties at public universities across the country shrunk significantly, some having disappeared completely. ${ }^{12}$ Many factors contributed to this crisis in theological education and Richardson lists the following as some of them: ${ }^{13}$ (a) changes in the funding bases, both the state and international donors; (b) national curriculum and education policy changes at the secondary school level; (c) the demise of ecumenism and a return to denominationalism; and (d) the subsequent threat of closure to a number of theological faculties. Within universities, various faculties were dismantled and reconfigured as part of human and social science, as schools, departments or units of theology and religion. Some moved from Christian theological training to a more general study of religion. Programme rationalisation, to increase efficiency and to harmonise curricula, also led to fewer theological courses in some institutions. For Bible colleges and

9 Cf. Neville Richardson, Ministerial Training and Theological Education in the Methodist Church of Southern Africa. The Road Ahead, in: Missionalia 35/2, 2007, 131-152, $132 \mathrm{f}$.

10 Cf. Daniel Levy, A Recent Echo. African Private Higher Education in an International Perspective, in: Journal of Higher Education in Africa 5, 2007, 197-220.

11 The number of public higher education institutions was reduced from 36 in 1994 to 23 in 2005. See Dreyer, Practical Theology (n. 6) for a detailed discussion of the restructuring process.

12 Examples include the universities of Western Cape, Fort Hare, Durban-Westville, Limpopo and South Africa. Theology faculties were closed at Rhodes University, the University of Zululand and the University of North.

13 Cf. Richardson, Methodist Church (n. 9), 133 f. 
seminaries the instability in theological education was impacted more strongly by the issue of accreditation and quality control. New institutions and mechanisms were put into place to deal with accreditation and authorisation such as the South African Qualifications Authority (SAQA) with its National Qualifications Framework. ${ }^{14}$ Previously the church-initiated Joint Board for the Theology Diploma provided accreditation. ${ }^{15}$ Each of the nineteen seminaries accredited with the Joint Board had to apply anew for accreditation, an expensive and technical exercise which many found difficult. ${ }^{16}$ This had a domino effect for seminaries - with some being unable to apply for accreditation for various reasons they were unable to attract students, which forced closures and merges. ${ }^{17}$ Also mainline churches found that with changing patterns of commitment and community resulting in shrinking church membership and fewer ministerial candidates, it became increasingly difficult to keep residential training programmes running. On the other hand, the declining pool of candidates for ordained ministry has resulted in increased programmes to equip laity for positions of leadership and service.

The nature of theological curricula and the quality of theological education varied greatly among different private theological institutions and universities. Therefore recognition and accreditation were important considerations especially in the case of students who move between institutions, usually with the aim of furthering their studies. Positively, accreditation forced theological institutions to be accountable to government, the Church and the general public and this could result in greater effectiveness. However this new system (SAQA) does not provide for any accrediting bodies other than itself. ${ }^{18}$ Theological institutions also have to

14 Legislation on the one hand created new opportunities for private providers to offer degrees, but on the other hand it imposed stringent requirements on providers outside the public system. These have included compliance with curriculum parameters laid down in the new national education policy as well as structural and institutional requirements relating to governance and quality assurance. Non-compliance carries the real threat of the refusal of registration and enforced closure.

15 In 1965, participating churches (Anglican, Methodist, Congregational Church) together established the Joint Board for the Diploma in Theology set up by the South African Council for Theological Education (SACTE) which included representation from across mainline denominations in Southern Africa; it became the chief accrediting body until the new South African educational legislation. A common diploma was awarded to students of colleges that operated under the Joint Board, with quality assurance being provided by the Board. Cf. Richardson, Methodist Church (n. 9), 144.

16 Cf. Richardson, Methodist Church (n. 9), 145.

17 For example, without accreditation the Anglicans and Methodists were forced to join Theological Education by Extension College (TEEC) for accredited training from 2005-2010.

18 This development of accreditation raises the issue that government bodies cannot be the only source for the assessment and accreditation of theological institutions. The Church will need to 
resolve the tension between the status of the institution as an autonomous authority with statutory recognition and an institution serving local Christian communities and churches. ${ }^{19}$

The increased levels of higher education change created instability from which university faculties, seminaries and churches are only now recovering. Each institution's struggle with identity - the definition and purpose and mission, the creation and abandonment of programmes and the search for fiscal stability profoundly affected the practice of teaching and learning. While restructuring and closure have been some of the responses to the crisis, many Bible colleges have spawned a variety of emphases and new degree programmes and found partnerships amongst universities. ${ }^{20}$ Whether in crisis or merely in painful transition, the fact is that many churches and theological institutions have engaged in a radical review of their theological education and ministerial formation programmes. ${ }^{21}$ The positive effect of these movements is, hopefully, stronger ecumenical cooperation among the various church denominations that have collaborated. However, some have legitimate fears that the wheeling-and-dealing has led to a "lowering of standards" in theological education. ${ }^{22}$

At the same time, the very contours of historic Christianity are changing as a result of the phenomenal growth of Pentecostal and independent churches in the

assist the theological institution in redefining the meaning of ministerial profession, the role of leadership and the educational formats that will serve the goals that emerge from these conversations. See Craig Dunsmuir / Michael McCoy, Accreditation and Ministerial Formation. Serving Two Masters?, in: Contested Issues in Training Ministers in South Africa, Stellenbosch (Sun Media) 2015, 38-53, for a discussion on how accreditation issues challenge ministerial formation.

19 Cf. Tony Moodie, TEE College of South Africa, in: Ross Kinsler (ed.), Diversified Theological Education. Equipping all God's People, Pasenda (William Carey International University) 2008, 47-80, $61 \mathrm{f}$.

20 North-West University has partnered with smaller Bible colleges like the Full Gospel Church of God, Apostolic Faith Mission, Auckland Park, Johannesburg, GeorgeWhitfield College while the University Kwa-Zulu Natal has partnered with the Seth Mokitimi Methodist Seminary, the Lutheran Theological Institute and St Joseph's Theological Institute, Cedara.

21 Presiding Bishop of Methodist Church of SA, Ivan Abrahams, instituted a Review Commission on theological education and ministerial training - the commission report was presented to the Conference in September of 2005; The Reformed church had various curatorial and ecumenical commissions - The A-Z Manual of the DRC (Nederduitse Geformeerde Kerk, The Kerkorde 2007, 87-92) quoted from Coenie Burger / Ian Nel, Ministerial formation in the Dutch Reformed churches. In search of new paradigms, in: Naidoo, Between the Real and the Ideal (n. 8), 17-32, $29 \mathrm{f}$.

22 Tinyeko Maluleke, Africanization, Liberation \& Transformation in Theological Education, Johannesburg (NICTE Publication) 1998, $14 \mathrm{f}$. 
global South. ${ }^{23}$ In South Africa there has been a dramatic increase in demand for general higher education due to a younger and dynamic population, which is also reflected in a growing demand for theological education especially among the African Independent Churches, Pentecostals and Charismatic networks. It would seem that the need for leaders far outstrips the ability of Bible colleges, seminaries and correspondence programmes to supply them. This mushrooming of new theological training institutions has, in turn, created tensions between public and private providers of theological education as they compete for students. The entrepreneurial marketing of theological education, valuing the student in terms of what they can consume or produce and the supermarket of theological offerings brings into focus the commodification and commercialization of theological education. The sudden growth in private theological education was partly because some traditions wanted to retain their specific identities and values which they perceived to be under threat. ${ }^{24}$ At the same time some church traditions ${ }^{25}$ have established their own ministerial training rather than looking to the traditional theological college or university. While it may be argued that most churches are not in a position to provide theological education at an appropriate post-secondary level, this developing pattern does demonstrate that the needs of the church have changed and may require different types of training. From these changes it is evident that there is a resurgence of denominationalism in theological education ${ }^{26}$ which is not a good sign for the integrity of Christian witness within the Protestant family. A genuine ecumenical commitment will not only acknowledge the differences between churches, but will work towards their reconciliation.

Currently Protestant and Catholic ${ }^{27}$ theological education, both undergraduate and post-graduate, is taking place at 9 of the 23 universities in South Africa, about 20 accredited private providers $^{28}$ and many non-accredited bible

23 Cf. Dietrich Werner, Challenges and Opportunities in Theological Education in the 21st century, Geneva (ETE/WCC) 2009, $38 \mathrm{f}$.

24 Cf. Levy, A Recent Echo (n. 10), 205.

25 This is evident in "The Charismatic Network" (TCN) of churches however local, churchintegrated theological education is in danger of becoming narrow-minded and sectarian, cf. Michael Neumann, Ministerial Formation in the Charismatic Context: Heads, hearts and hands, in: Naidoo, Between the Real and the Ideal (n. 21), 133-145.

26 Naidoo, Between the Real and the Ideal (n. 8), 1-180.

27 With 7\% of the population being Catholic, theological training takes place mostly at St John Seminary for diocesan candidates and St Joseph's Theological Institute for religious congregations, cf. Susan Rakoczy, Formation of candidates for the Catholic priesthood in South Africa, in Naidoo, Between the Real and the Ideal (n. 8), 115-129.

28 Cf. www.dhet.gov.za/Registers; Register of Private Higher Education Institutions, Department of Higher Education and Training, updated 7 April 2015. 
colleges. The approach to theological education is markedly different ranging from confessional to critical correlation with social sciences to contextual approaches. ${ }^{29}$ There are shifting expectations and denominational differences as to what the ordained ministry and church leadership should entail. This make the task of training ministers that more challenging. Descriptors such as "evangelical", "conservative", "ecumenical", "liberal" or "contextual" provide better insight into the rather tangible divides in this regard.

Practical theology as a field of scholarship is committed to ministerial formation and as a discipline ${ }^{30}$ it focuses strongly on the "clerical paradigm" reflecting the important need of ministerial training. It is found in 8 universities and in many, if not all denominational seminaries and bible colleges with their strong focus of skills training. It is also one of the fastest growing disciplines in all South African universities that offer theological training. Within universities the goal of theological education is about the creation of theological knowledge through engaging in research - Wissenschaft - whereas denominational seminaries are primarily about preparing professional clergy for the Church - vocatio - with a focus on character education - paideia. As Bosch ${ }^{31}$ states theology in the university tends towards the analytical, rational study of religions or theology with little attention paid to spirituality and practice. "Generally university theology is done outside the control of the church." ${ }^{32}$ Seminaries and theological colleges on the other hand are usually geared towards training ministers, are often denominationally organised, and have as one of their goals the formation of the potential minister for service in the particular denomination. However, in both examples the scholastic model is followed. Like many university faculties, teaching and learning in denominational seminaries and bible colleges have an unmistakable academic cast that emphasises cognitive mastery of concepts and knowledge. The reality is that the new scramble for accreditation under the South African Qualifications Authority (SAQA) without which theological departments and seminaries

29 Cf. Coenie Burger, Practical Theology in South Africa. An Examination of the Thoughts on Certain Presuppositions of the Discipline, Pretoria (RGN) 1991. See Christian Landman, Theological Education in South Africa, in: Isabel Phiri / Dietrich Werner (eds.), Handbook of Theological Education in Africa, Pietermartizburg (Cluster) 2013, 237-245, for what the major public universities and private providers are currently offering in terms of theological programmes.

30 The subject-discipline has a professional society, Society for Practical Theology in South Africa (SPTSA) and an accredited academic journal, Practical Theology in South Africa (PTSA). See Dreyer, Practical Theology (n. 6) for a discussion on Practical Theology in South Africa.

31 Cf. David Bosch, The Nature of Theological Education, in: Journal of Theology for Southern Africa 77, 1991, 3-17.

32 Bosch, Theological Education (n. 31), $8 \mathrm{f}$. 
will be hamstrung, forces this academic model upon them and has had severe consequences for theological institutions.

\section{The Focus of Ministerial Formation}

Since the systematisation of Christian theology in $19^{\text {th }}$ century Germany, practical theology was viewed merely as applications of truth found within systematic theology. Farley ${ }^{33}$ profoundly critiqued the classical four-fold division of theological education, noting its inadequacy to support the clergy paradigm of ministry with its focus on instrumental skills. This critique led to some of the key contributions including those by Charles Wood, ${ }^{34}$ who emphasized theology as a process of critical inquiry; Joseph C. Hough, Jr., and John B. Cobb, Jr., ${ }^{35}$ who tried to give more content to Farley's proposal by focusing on Christian identity; the Mud Flower Collective, ${ }^{36}$ which brought a feminist critique to the conversation with an emphasis on story and the voice of the marginalized; Hough and Barbara G. Wheelerm, ${ }^{37}$ who placed the conversation into the context of the congregation in order to break free from the clerical paradigm; Rebecca Chopp, ${ }^{38}$ who constructed an approach to theological education around feminist practices; Max Stackhouse, ${ }^{39}$ who brought theological education into conversation with globalization, contextualization and mission and David Kelsey, ${ }^{40}$ who reframed the "Christian thing" in theological education as an effort to understand God truly.

These scholars were trying to frame an approach for keeping God, whether directly or indirectly, in the conversation about theological education. To do this

33 Edward Farley, Theologia. The Fragmentation and Unity of Theological Education, Philadelphia (Fortress Press) 1983.

34 Charles M. Wood, Vision and Discernment. An Orientation in Theological Study, Atlanta (Scholars Press) 1985.

35 Joseph C. Hough / John B. Cobb, Christian Identity and Theological Education, Atlanta (Scholars Press) 1985.

36 The Mud Flower Collective, God's Fierce Whimsy, New York (Pilgrims Press) 1985.

37 Joseph C. Hough Jr. / Barbara G. Wheeler, Beyond Clericalism. The Congregation as a Focus for Theological Education, Atlanta (Scholars Press) 1988.

38 Rebecca S. Chopp, Saving Work. Feminist Practices of Theological Education, Louisville (Westminster John Knox) 1995.

39 Max L. Stackhouse, Apologia. Contextualization, Globalization and Mission in Theological Education, Grand Rapids (Eerdmans) 1988.

40 David H. Kelsey, To Understand God Truly. What's Theological about a Theological School, Louisville (Westminster John Knox Press) 1992. 
there was general agreement regarding the importance of collapsing the Enlightenment divide between theory and practice and undoing the unfortunate marginalization of practical theology. The proposed reconstruction was toward finding some way to reintegrate theological knowledge (theoria) with practical wisdom (phronesis) and for these to be shaped by personal (paideia) and communal (habitus) formation. ${ }^{41}$

Within the broader discipline of practical theology the questioning of the clerical paradigm entailed a transition from a therapeutic to a hermeneutical model of pastoral engagement ${ }^{42}$ in which the activity of theological reflection assumes centre stage with a particular methodology for reflection. ${ }^{43}$ Experience has also become an important category as the root of critical understanding, leading to action. Similarly within ministerial formation there has been a turn away from teaching pastoral functions towards educational methods and practices to form reflective practitioners, ${ }^{44}$ not only reflecting about practice, but reflecting in practice. ${ }^{45}$ In this frame, expertise is only ever articulated in relation to the field of practice and is therefore always contextual and contingent, respecting the particular situation. It intersects and dialogues with other fields and engages the normative resources of the Christian faith.

It is important to note that historically practical theology was typically aligned to pastoral functions as pastoral theology $\mathrm{y}^{46}$ in such as way that the former became the field's entire focus. To avoid confusion, the term pastoral theology is not used as it relates too closely to "pastoral care"; as Miller-McLemore suggests, practical theology is "integrative, concerned about issues of ministry, discipleship; pastoral theology is person- and pathos -centered." ${ }^{47}$

Many schools of theology are again envisioning theological education as a formational activity; an activity based on the assumption that the student's personal appropriation of theology is the most central aspect of theological

41 Cf. Craig van Gelder, The Missional Church \& Leadership Formation, Grand Rapids (Eerdmans) 2009, $33 \mathrm{f}$.

42 Cf. Richard R. Osmer, Practical Theology. An Introduction, Grand Rapids (Eerdmans) 2008.

43 Cf. Elaine Graham / Heather Walton / Frances Ward, Theological Reflection. Methods, London (SCM Press) 2005, 2f.

44 Cf. Donald A. Schön, The Reflective Practitioner. How Professionals Think in Action, New York (Basic Books) 1984.

45 Cf. Hough / Cobb, Christian Identity (n. 35).

46 Cf. Gerben Heitink, Practical Theology. History, Theory, Action Domains. Manual for Practical Theology, Grand Rapids (Eerdmans) 1999, $310 \mathrm{f}$.

47 Bonnie Miller-McLemore, Five Misunderstandings about Practical Theology, in: IJPT 16, 2012, $5-26,17 \mathrm{f}$. 
education. ${ }^{48}$ Ministerial formation is viewed as a multi-faceted activity involving critical thinking, the acquisition of knowledge, skills development, religious identity formation and the development of ministerial and spiritual maturity expected of church ministers. ${ }^{49}$ This formational notion of theological education is what Farley labels as theologia, rather than theology, in order to underline that it is a kind of personal wisdom, a way of being human. However, theologia requires disciplined reflection in order to achieve this purpose and this comes through the modes of theological reflection, theological understanding and theological knowledge..$^{50}$ For Farley practical theology must find its coherence in ecclesial presence - the historical reality of the Church and its mission and presence in the world with attention to the normative and eschatological calling of the Church. It is a model of learning in which faith, study and tradition inform one another ${ }^{51}$ and thereby foster the development of the person. This is a process viewed not simply as something that is done to students, but rather as a cooperative and intentional journey which engages the interests, time, skill and creative energies of the student and congregation and further enlists the enabling resources of theological educators who carry a mandate to provide the link between education and ministry foundation..$^{52}$ However, this habitus can occur outside the structure of a theological curriculum and is the province of all people. ${ }^{53}$ Ministry is no longer solely equated with the activities of ordained ministry, but rather something exercised by the whole people of God, in church and world. ${ }^{54}$

Future church leaders need the integration of practices, beliefs and desires through communal settings that emphasise catechesis, critical reflection and faithful living in this world..$^{55}$ This is necessary because people are shaped by the complex interrelations between what they do, what they think and what they

48 Cf. Charles Foster / Lisa E. Dahill / Lawrence Golemon / Barbara Wang Tolention, Educating Clergy. Teaching Practices and Pastoral Imaginations, San Francisco (Jossey Bass) 2006.

49 Cf. Paul Overend, Education or Formation: the Issue of Personhood in Learning for Ministry, in: Journal of Adult Theological Education 4/2, 2007, 133-148.

50 Cf. Farley, Theologia (n. 33), 156-158f.

51 Cf. Paul Ballard / John Prithard, Practical Theology in Action. Christian Thinking in the Service of Church and Society, London (Liturgical) 1996, 69f.

52 Cf. Linda Cannell, Theological Education Matters - Leadership Education for the Church, Newburgh, IN (Edcot Press) 2006.

53 Cf. Farley, Theologia (n. 33), 159 f.

54 Cf. World Council of Churches, 1982, Baptism, Eucharist and Ministry, Faith and Order Paper No. 111, Geneva (WCC), 1982.

55 Cf. L. Gregory Jones, Beliefs, Desires, Practices and the Ends of Theological Education, in: Miroslav Volf / Dorothy C. Bass (eds.), Beliefs and Practices in Christian Life, Grand Rapids (Eerdmans) 2002, 185-204. 
passionately want. As Gregory Jones suggests this was particularly apparent in the social engagement of resisting apartheid, ${ }^{56}$ where many congregations in South Africa in fact catechised people in ways that supported the ideology of apartheid. Similarly, universities and other institutions of formal learning developed curricula to reinforce that ideology. Yet there were seminaries ${ }^{57}$ that raised crucial challenges to apartheid's intellectual and theological rationale and supported congregations and individuals in their resistance against it. Seminaries shaped and formed students to challenge the broader patterns of social life that oppressed the majority of South Africans. They enabled students to understand the task of catechesis and seminary education in deeper and more transformative ways. These mutually reinforcing movements of Christian education and formation were crucial to the leadership of such key figures as Archbishop Desmond Tutu, Bishop Peter Storey and Reverend Beyers Naudé. But they were equally significant in shaping the faithful witness of countless other pastoral leaders and laypeople. These broader pedagogical movements shaped beliefs and practices within communal contexts to form and educate persons for leadership.

\section{Challenges for Ministerial Training}

Within our context, many challenges exist for ministerial training amidst pressing ministerial needs. To begin with, a critical challenge is that the telos for ministerial formation is contested in public university models. If practical theology involves the cultivation of pastoral imagination and practical wisdom,,$^{58}$ the clarification of vocational identity and the development of competence in pastoral skills, one needs a habitus, ${ }^{59}$ an integrated curriculum for this to materialize. It is widely recognized that the focus in the curriculum has been on the academisa-

56 Cf. ibid., 189.

57 The Federal Theological Seminary of South Africa (Fedsem) was established in 1967. In response to the exclusion of apartheid, a small number of the "English speaking churches" in southern Africa; the United Congregational Church of Southern Africa, the Presbyterian Group of Churches in Southern Africa, the Methodist Church of Southern Africa and the Church of the Province of South Africa rallied together and created an alternative to the government sponsored theological education facilities for blacks, coloureds and Asians. Unfortunately, ecumenical theological education in South Africa, which survived over four decades of apartheid, did not survive the decade of liberation, as the seminary was closed in 1993 for various reasons. Cf. Richardson, Methodist Church (n. 9), 144,

58 Cf. Dorothy C. Bass / Craig Dykstra (eds.), For Abundant Life. Practical Theology, Theological Education and Christian Ministry, Grand Rapids (Eerdmans) 2008.

59 Cf. Ballard / Pritchard, Practical Theology (n. 51), 35-37. 
tion of theological education with administrative and disciplinary silos, when integration is really required. In addition, the pressures of academic life, the need to comply with academic systems of quality assurance, competing schools of theology and individual interests and ambitions, does not allow space for formation in the university context. Also, academics are appointed less for their personal capacities to be midwives of students' coming to an understanding of God and of themselves; rather the focus is on the ability to cultivate capacities for scholarly research in students. It would be difficult to seek to instil a specific habitus among theology students in a university classroom where similar church backgrounds or at least shared vocational trajectories cannot be assumed. The openness of the over-crowded curriculum itself aids the "consumer mentality" of our culture, thus reinforcing the character and values of students and frustrating the faculty's attempt to become involved. The inner coherence and church-related responsibility of theological education cannot be exercised if the structural framework does not allow a formational emphasis.

Since the time of Schleiermacher many have espoused the notion that theological scholarship can be completely or largely detached from concerns related to the faith commitment of the theological student, which has forced the question of what is "theological" about theological education? ${ }^{60}$ The practical, pastoral, or clinical side of the curriculum tends to be equally remote from personal appropriation and internationalisation. The goals of the traditional intellectual approach, shaped by its Western views of rationality found in universities, often omit personal formational elements, despite evidence that students in these courses often enrol for formational reasons. ${ }^{61}$ University faculties have become so diversified that theological disciplines are no longer able to converse meaningfully with one another. Each discipline has its own methodology and, hence, its own language and because of this it loses its capacity to reflect on a common goal for ministerial formation. Maybe because of the diffused nature of practical theology, even within the discipline of practical theology itself - modules on pastoral actions are taught in isolation. These should instead have greater connection with other sub-disciplines ${ }^{62}$ to show the overlap and the interconnectedness of minis-

60 Cf. Kelsey, To Understand God Truly (n. 40).

61 Cf. S.L. Graham, Theological education on the web. A case study in formation for ministry, in: Teaching Theology and Religion 5/4, 2002, 227-235.

62 Academics in universities in South Africa use mostly the critical correlation, and few use contextual approaches and typically share some common methodological assumptions. Even though the field is still focused on the clerical paradigm, there are no common theoretical or pedagogical strategies for the training of ministers. 
try. ${ }^{63}$ Education for ministers should move beyond the tendency to impart information on certain core areas of ministry and the development of preferences among the available options. The process of teaching practical theology should involve a back and forth rhythm between performance and critique, essential to embody what is being taught. Teaching involves teaching a practice ${ }^{64}$ with the appropriate modelling as well, which calls for a theological pedagogy. ${ }^{65}$ As Miller-McLemore suggests, teaching in this field is a particular way of theological knowing, phronesis, that has important implications not only for the teaching of practical theology but also for the definition of the field itself. ${ }^{66}$

Integration refers to attempts to synthesise and coordinate the major learning experiences in a programme. It includes the integration of theological disciplines with each other; the integration between theory and praxis; and the dynamic interplay of knowledge, practice, and context - knowing, doing and being. ${ }^{67}$ Methodologies within practical theology must help students understand how theory and practice relate and hence practical theology must assert its methodological unity. The task is to concretise with greater precision the theoretical principles that make up practice and to enrich theoretical propositions on the basis of practical experience. In the last three decades of scholarship in practical theology, many have argued that theory and practice "dialectically" influence each other. ${ }^{68}$ The goal of ministerial formation is to integrate the cognitive, affective and behavioural components of the practice of ministry and unless the primary aim is recognized as valid theological institutions will continue to pertetuate the theory-practice dichotomy.

Within the South African context, universities and seminaries miss opportunities to prepare people for Christian social engagement through study that links theology and congregational life to the concerns and structures they will encounter. More should be done in terms of training in the functions of ministry ${ }^{69}$ within

63 Cf. Osmer, Practical Theology (n. 42), $15 \mathrm{f}$.

64 Cf. Bonnie Miller-McLemore, Practical Theology and Pedagogy. Embodying Theological Know-How, in: Bass / Dykstra, For Abundant Life (n. 55), 170-193, 172 f.

65 Cf. Kathleen A. Cahalan / James R. Nieman, Mapping the Field of Practical Theology, in: Bass / Dykstra, For Abundant Life (n. 55), 62-90, 76 f.

66 Cf. Miller-McLemore, Practical Theology and Pedagogy (n. 64), 171.

67 Cf. Kathleen A. Cahalan, Integration in Theological Education and Ministry. Initial Findings from the Collegeville Institute Seminars, Paper presented at the International Academy of Practical Theology, 2011.

68 Farley talks about a "dialectic of interpretation" of truths and norms of the tradition and concrete situations of everyday life. Cf. Farley, Theologia (n. 33), 165.

69 In the Reformed tradition, a study on "Perception on Theological Training Among Alumni (2000-2005)" in the Unit for Religion and Development Research at Stellenbosch University 
the theological curriculum with greater integration or ecclesiastical supervision ${ }^{70}$, so that ministry training is not left to become an appendix of the training model. While many institutions encourage students to get involved in community service, they rarely link such activity to critical reflection about that service or tie it to the content of courses. Thus the gap in the interweaving of time spent acquiring knowledge and using it, practising ministry and reflecting on it, are still too great. The reality is that many graduates or ordinates are being re-tooled for ministry, as denominations are now enhancing their continuous training programmes. ${ }^{71}$

In spite of the developments towards a more holistic view of the individual learner in higher education, the dissonance between educational philosophy and theological understanding of the person and of formation would seem to suggest that universities are not an ideal partner in learning for ministry. ${ }^{72}$ Structural partnerships are generally difficult because of divergent institutional aims ${ }^{73}$ and this is very evident in the South African context where ministerial training is essentially an academic exercise with some variation of ministry exposure. Universities do not attend to ministerial formation, which is a task left for students to address via their denominations. One exception to this is that four universities within the Reformed tradition have an additional "curatorium" (devotional space) for their Reformed students, which attempts to attend to students' spirituality and ministerial development. However, in a recent study on the intentionality of spiritual formation in Protestant theological institution, ${ }^{74}$ it was found that students in the university models, including that of the Reformed and Presbyterian traditions, were least likely to support this. The intention of spiritual formation may be obscured by accreditation demands, the marginalization of spirituality in the life of the university, the lack of community and the compartmentalisation of

found the need for and importance of ministerial skill were indicated as the most important priorities. The basic management of the congregation, with preaching, pastoral and teaching skills were specified as lacking in ministerial training, cf. Coenie Burger / Ian Nel, Ministerial formation (n. 21), $20 \mathrm{f}$.

70 Cf. Hough / Cobb, Christian Identity (n. 35), $46 \mathrm{f}$.

71 Post-ordination Training (POT) with the Anglican Church of South Africa, Apostolic Faith Mission have launched a Pastors Continuous Development (PCD) programme since 2013 linked to ministerial status renewal with the denomination, the Reformed tradition has enhanced training since 2007 which is compulsory, cf. Coenie Burger / Ian Nel, Ministerial formation (n. 21), $28 \mathrm{f}$.

72 Cf. Overend, Education or Formation (n. 49).

73 Cf. Gary Wilton, The Hind Report. Theological Education and Cross Sector Partnerships, in: Discourse. Teaching and Learning in Philosophical and Religious Studies 7/1, 2007, 153-178, $158 \mathrm{f}$. 74 Cf. Marilyn Naidoo, An empirical study on Spiritual Formation at Protestant theological training institutions in South Africa, in: Religion and Theology 18/4, 2011, 118-146. 
theological disciplines. ${ }^{75}$ The theological notion of formation reveals that educational methodologies in higher education fall short of a desirable model of learning for ministry. ${ }^{76}$

We move now from how we teach, to what we teach which speaks to our social location and identity. Theological education is invariably shaped by the larger political, economic and social forces, and social transformation exerts pressure on ministerial training. Like everything else, theological education has also been divided with different systems of training for different racial groups. Denominations have gone through a process of reformulating their identity and have restructured theological education for all their members, resulting in growing multi-cultural student bodies. ${ }^{77}$ Some denominations have made progress in unifying different streams of training, but more work needs to be done in terms of reconciliation. One wonders what kind of Christians such a church will form with its accompanying theological training institutions. ${ }^{78}$ There is a need to work towards becoming part of the collective, towards a new nation, a common African-ness. Ubuntu (personhood or humanness), as Gathogo ${ }^{79}$ points out, entails among other things, the notion of hospitality. As Kritzinger suggests, what is sorely needed is for us to affirm our connectedness and solidarity with all people around us: "What we need as an underlying ethos for everything we do in ministerial formation is a spirituality of inclusion, reaching out to people who are different, thinking them into our lives as part of our world view; a way of life that does not say (or even think): 'the coloureds have a gangsterism problem', 'the Afrikaners have a racism problem', or 'the poor black communities have a xenophobia problem', etc. Instead, it will say: 'we have a gangsterism problem in some of our townships', 'we have a racism problem in some of our communities', 'we struggle with a hatred for foreigners in some of our communities', etc." "80

As a new South Africa emerges, churches must find their role as an agent of reconciliation, as "they are positioned to take the lead in confessing sins of racial prejudice and hatred, and inspiring commitments to economic jus-

75 Ibid, $140 \mathrm{f}$.

76 Cf. Overend, Education or Formation (n. 49), $145 \mathrm{f}$.

77 Dreyer, Practical Theology (n. 6), $511 \mathrm{f}$.

78 Cf. Marilyn Naidoo, Transformative Remedies Towards Managing Diversity in South African Theological Education, in: HTS Teologiese Studies/Theological Studies 76, 2015, 1-7.

79 Julius Gathogo, Revisiting African Hospitality in Post-colonial Africa, in: Missionalia, 35/2, 2007, 108-320.

80 Cf. Johannes Kritzinger, Ministerial Formation in the Uniting Reformed Church in Southern Africa. In Search of Inclusion and Authenticity, in: Naidoo, Between the Real and the Ideal (n. 8), $40 \mathrm{f}$. 
tice and social transformation." 81 This point was taken forward by Stanley Hauerwas $^{82}$ when he said that the church community itself is an education. Churches are mediating institutions between the private and public spheres ${ }^{83}$ and have the potential to draw people out of their private, racially segregated lives, into a social space where human interactions are more intimate than the public arena. In addition, the once privileged status of theology in public universities has now to earn its right to continue in a new multi-religious environment. As Mouton suggests, "any ghetto theology" will not be tolerated but a call for a bold, unthreatened conversation within its orientation. ${ }^{84}$

As we know the history of theological education in this region has basically been characterised by foreignness, that is, foreign theological content, methodology and languages. In recent years, theological educators have realised the need to take African culture seriously in order to produce a relevant theology for the African people (Mudimbe 1988; Ela 1986; Bediako 1992; Tienou 1984). Maluleke's ${ }^{85}$ call to Africanise theological education explicitly illustrates one of the ways in which as a hermeneutical trope, Africa frames the possibility of discourse on identity, culture and theology. Africanisation means more than just the teaching of or inclusion of black and African issues in curricula, but also the "mainstreaming" of African issues in theological education. ${ }^{86}$ It begins when theological education develops contextual approaches and hermeneutical methods based on the way African people conceive and interpret reality; Christianity based on spiritual worldviews, supernatural powers, pre-Enlightenment concepts, charismatic power or supernatural energies of the Holy Spirit. The idea is that the Church needs to become African in belief, theology and practice for it to be truly African. ${ }^{87}$ Bediako notes that this search actually constituted a new theological

81 Thomas Frank, Leadership and Administration. An Emerging Field in Practical Theology. Research Report, in: IJPT, 10, 2006, 113-152, 148 f.

82 Stanley Hauerwas, Christian Living Today. Essays on Church, World and Living in Between, Durham, NC (Labyrinth Press) 1988, 181f,

83 Cf. Timothy B. Smith / Christopher R. Stones / Christopher E. Peck / Anthony V. Naidoo, The Association of Racial Attitudes and Spiritual Beliefs in Post-apartheid South Africa, in: Mental Health, Religion and Culture 10/3, 2007, 263-274.

84 Cf. Elna Mouton, Christian Theology at the University. On the Threshold or in the Margin?, in: HTS, 64/1, 2008, 431-445, $438 \mathrm{f}$.

85 Cf. Maluleke, Africanization (n. 22).

86 Maluleke, Africanization (n 22).

87 Cf. Paul Bowers, African Theology. Its History, Dynamics, Scope and Future, in: African Journal of Evangelical Theology 21/2, 2002, 109-125, 111f. Catholic reflection has vigorously debated whether adaptation or incarnation is the more appropriate theological methodology, while one strand of Catholic reflection has also probed into the underlying world views or 
methodology, the "hermeneutic of identity," ${ }^{88}$ not sourced in a Western dominated model of theological engagement, but in a genuinely biblical encounter with their religious past. One of the success stories of African theology has been African Women's Theologies to promote theological research and reflection from African women's perspectives and experiences. It was established by the Circle of Concerned African Women Theologians in 1989 in Accra, Ghana, and is a movement that gained great momentum in South Africa and at South African universities through women lecturers in theology and engendering theological curriculum in content and pedagogy. ${ }^{89}$ However, much work still needs to be done as theologians are called upon to adopt liberative hermeneutical paradigms enabling Christians to transcend the patriarchal domination.

Christians can no longer afford to ignore the issue of Africanisation in their congregations and ministerial formation. Africanisation reflects the common legacy, history and post-colonial experience. ${ }^{90}$ The work of Ntisame ${ }^{91}$ from a Lutheran perspective, Kritzinger advocating for an African Reformed ministerial formation ${ }^{92}$ as well as Richardson and Leleki ${ }^{93}$ from a Methodist perspective show that denominations are re-imagining their ministerial formation. The question has to be asked anew: "What does it mean to practise theology in an African

"implicit philosophies" of traditional Africa. Protestant reflection has often led the way in looking for points of contact between standard themes of Christian theology (such as revelation, sin, Christology or eschatology) and those values, institutions, concepts and symbols which underlie African culture. Church leadership issues tend to focus on the pastoral and catechetical needs of the believing Christian community, especially as it is affected by traditional culture, for example, with respect to rites of passage, polygamy, liturgical custom, divination, traditional healing or the role of ancestors.

88 Kwame Bediako. Theology and Identity. The Impact of Culture upon Christian Thought in the Second Century and Modern Africa, Oxford (Regnum Books) 1992, $16 \mathrm{f}$.

89 Cf. Isabel A. Phiri, Major Challenges for African Women Theologians in Theological Education (1989-2008), in: International Review of Mission 98/1, 2009, 116-134.

90 Cf. Willa P. Louw, Africanisation. A Rich Environment For Active Learning on a Global Platform, in: Progressio 32/1, 2010, 42-54.

91 Radikobo Ntsimane, The Fragile Identity of Being Lutheran and African. The Vulnerability of Confessional Lutheran Seminaries in Africa Today, in: Studia Historiae Ecclesiasticae 36/2, 2010, 219-235.

92 Kritizinger, a missiologist, identifies three dimensions in the Uniting Reformed Church of South Africa, namely, praxis-based, focused on diversity and a specific language policy. Cf. Johannes Kritzinger, Ministerial Formation Praxis in the Uniting Reformed Church in Southern Africa. In Search of Inclusion and Authenticity, in: Naidoo, Between the Real and the Ideal (n. 8).

93 Neville Richardson/ Sox Leleki, From Ecumenical Experiment, to Denominational Necessity, to Holistic Vision. The Methodist Journey in Ministerial Training, in: Missionalia 38/2, 2010, 235-247. 
context beyond the borders of a European and North American paradigm." ${ }^{94}$ Not only is practical theology in South Africa "too dependent on practical theology in the northern hemisphere," 95 it also very much represents the Reformed tradition, with four reformed universities and many academics employed from this tradition in universities. The discipline, including even agendas for ministry training, is influenced by a "white-Reformed approach not representative of the religious demographics of South Africa." 96 The tendency for a 'private theology' can support trends in which "white South African churches live and worship in safe cultural enclaves whilst simultaneously discriminating against people of another culture." 97 The complexity of the South African theological praxis will call for an approach that takes on a diversity of perspectives of cultural, public and Christian life. The concept of pastoral ministry should be broadened to include service to those at all levels of the social ladder. ${ }^{98}$ Contemporary voices call on practical theology to become more contextual, practical or relevant rather than being a highly theoretical discipline, with a growing distance between the academy and the local church. Future leaders will need to be interpreters and mediators between the local and the global, what sociologist Roland Robertson describes as "glocal" ", which will require a multiperspectival approach with appropriate curricular modifications in ministerial and missional modes. ${ }^{100}$ Globalization has

94 Daniel J. Louw / Elna Mouton, Die Fakulteit Teologie op die wipplanlk tussen verrassing en ontnugtering, waarheid en pyn, in: Pieter Coertzen (ed.), Teologie Stellenbosch 150+, Wellington (Bybelmedia) 2009, 53-72, 54f, cf. Burger / Nel, Ministerial formation (n. 21), $20 \mathrm{f}$.

95 Dreyer, Practical Theology (n. 6), $512 \mathrm{f}$.

96 Quoted in Kobus Schoeman, / Martin Laubscher / Joseph Pali / Jan-Albert van der Berg, Practical Theology at a Public University: the Road Travelled and the Road Ahead at the University of the Free State, in: Rian Venter / Franncois Tolmie (eds.), Transforming Theological Knowledge, Stellenbosch (Sun Media) 2012, 127-145, $136 \mathrm{f}$.

97 Cf. Johan Cilliers / Ian A. Nell, "Within the Enclave”. Profiling South African Social and Religious Developments since 1994, in: Verbum et Ecclesia 32/1, 2011, 4-6. $5 \mathrm{f}$.

98 See Dames for a discussion on how to deal with knowing, believing and living amongst diverse cultures in the light of the gospel, Gordon E. Dames, Knowing, Believing, Living in Africa. A Practical Theology Perspective of the Past, Present and Future, in: HTS Teologiese Studies/ Theological Studies 69/1, 2013.

99 Robertson said that glocalization "means the simultaneity - the co-presence - of both universalizing and particularizing tendencies." Roland Robertson / Kathleen E. White, Globalization. An Overview, in: Roland Robertson / Kathleen E. White (eds.), Globalization. Critical Concepts in Sociology, Vol. I, London (Routledge) 2003, 1-44. In South Africa, an example of glocal theology is the postfoundationalist practical theology which is reinventing the basic practices of practical theology through local and informal formational practices. Julian C. Müller, A Postfoundationalist, HIV-Positive Practical Theology, in: Practical Theology in South-Africa 20/2, 2005, 72-88.

100 The pluralistic realities in life require an effective methodology that can respond to such a challenge. 'Transversality' explores various factors which overlap and diverge in concrete dialo- 
catalysed the colonisation of African ways of knowing. ${ }^{101}$ Hence it will involve a commitment from all critical and transformative theological educators in Africa to have Africa as their focus, embracing indigenous African epistemologies in the transformation of theological discourses. ${ }^{102}$

Theological education, then, must move away from private faith to have a critical-prophetical role; to articulate the public role and responsibility of Christian witness in relation to current trends, challenges and shortcomings in society. As Landman states, "public theology has become big business in South African universities [...] to put both the decline of public morality and practices on the table." ${ }^{103}$ Despite the contested nature of the Church and its involvement with the community ${ }^{104}$, public theology must create a critical awareness of situations and be present and involved in the lives of people, entering into dialogue with the reality of the situation. Boesak is scathing in his criticism, that the South African Church $^{105}$ cannot speak prophetically as it has not dealt effectively and honestly with the past and its guilt, that there is no meaningful political and social insight because the church is effectively still isolated and isolationist, and that there is no theology for the public responsibility it is called to.

Added to these concerns are other pressing challenges in our context: the questionable economic viability of seminaries, the effective use of information technologies for theological teaching, managing diversity in theological education, the need for dialogue with indigenous theology and the lack of multi-faith training, to name but a few.

gue between the cultural perspectives of particular communities. Osmer, Practical Theology (n. 42), 172.

101 Cf. Jacinta M. Maweu, Indigenous Ecological Knowledge and Modern Western Ecological Knowledge. Complimentary, not Contradictory, in: Thought and Practice. A Journal of the Philosophical Association of Kenya 3/2, 2011, 35-47, 36.

102 Cf. Phillip Higgs, The African Renaissance and the Decolonisation of Theological Education, in: Marilyn Naidoo (ed.), Contested Issues in Training Ministers in South Africa, Stellenbosch (Sun Media) 2015, 86-98.

103 Landman, Theological Education (n. 29), 240.

104 Johannes C. Erasmus / A. Louw / Willie van der Merwe, Changing Landscapes of Welfare, Religion and Gender. The Impact on the Role of the Churches, in: Journal of Theology for Southern Africa 133, 2009, 8-25.

105 Allan A. Boesak, Theological Formations in South Africa. Challenges and Opportunities, in: Rian Venter / Francois Tolmie (eds.), Transforming Theological Knowledge. Essays on theology and the university after apartheid, Bloemfontein (Sun Media) 2012, 105-110, $109 \mathrm{f}$. 


\section{Research Opportunities}

Even as the discipline has broadened the focus and moved away from a clerical paradigm, there remains a special responsibility to educate and form ministers in service to church and society. In the South African scene research has been fragmented according to the historic sub-disciplines of kerygma, leitourgia, didaskalia, and diakonia including the communal, theological and practical features. ${ }^{106}$ Research is conducted within each of these fields by academic theologians and post-graduate students in various universities, in the main based on an ecclesiological understanding of the field. ${ }^{107}$ Each scholar has to be concerned not only with their field of specialisation but with the unity of theology in which the ministerial task/church ministries provides the unifying task. There is a need to understand the question of how practical theology shapes the ministry curriculum as a whole or how it defines the various sub-disciplines that make up the curriculum and relates them to each other. At the same time there is a need to understand what is distinctive about pedagogy in practical theology, as embodied in concrete practices in the classroom. With the formational mandate, academics and teachers need to understand this process, the role of self-reflection and the student's personal and communal transformation. ${ }^{108}$

Research in ministerial formation must be about simultaneously transgression of several boundaries, including those that divide the curriculum four-fold, as well as those between disciplines of study and the wider university and particularly between the seminary and the Church. A dialogical and inter-disciplinary approach will inform faith and life in Africa with a greater degree of credibility and confidence. Within the curriculum a useful integrative concept in the United States is that of "reflective practice." 109 This may be the most constructive way to address both scripture and ecclesial tradition within contemporary situations and the context of cultural changes. As Frank suggests, the field still

106 Examples include: Matsobane J. Manala, A Triad of Pastoral Leadership for Congregational Health and Well-being. Leader, Manager and Servant in a Shared and Equipping Ministry, in: HTS Teologiese Studies/Theological Studies 66/2, 2010; Ian Nel, Teaching Leadership and Administration at a Faculty of Theology. Practical-Theological Reflections, in: Scriptura 113/1, 2014, 1-18.

107 Cf. Jaco Dreyer, Practical Theology in South Africa. Recent Developments and New Challenges. Keynote paper delivered at the conference of the Society for Practical Theology in South Africa, Practical Theology in South Africa. Perspectives and paradigms, Pretoria 2010, 7.

108 Cf. Kathleen Cahalan / Carol Lakey Hess / Bonnie Miller McLemore, Teaching Practical Theology. Introducing Six Perspectives, in: IJPT 12, 35-87, 80.

109 Cf. Schön, Reflective Practitioner (n. 44). 
needs much more exploration of how reflective practice actually works. ${ }^{110} \mathrm{New}$ understandings are needed into the support and apprenticeship that leaders require before, during and beyond their time spent in theological education. For example, institutions' contribution to life-long learning would include professional continuing education programmes, but they would also include lay-people independent from formal degree programmes. This will also involve ongoing and sustained engagement with church ministers and academics in the production of practical theological thinking and writing.

In terms of methodology, Africans are more aware of the need to pay attention to present-day issues of concerns to Africans, and all things African has to be partial, provisional and contextual. The analytical and descriptive tools of the social science in doing empirical research, is key to understanding and interpreting ministerial training situations. ${ }^{111}$ Also important is how indigenous African epistemologies and educational discourses, for example including the role of community knowledge, can be tapped as a foundational resource for theological education. What is needed is more support for a contextual theology ${ }^{112}$ or a liberationist practical theology ${ }^{113}$ that recognize the social positioning of those doing theology, a theology that is relevant to oppression and exclusion from a non-Western perspective.

Currently empirical research projects in ministerial formation, funded by the National Research Foundation, have covered areas of spirituality in formation ${ }^{114}$ and diversity in theological education. ${ }^{115}$ Recent publications include edited volumes; Between the Real and the Ideal: Ministerial Formation in South African Churches (2012) discusses ministerial processes in the various mainline and independent Protestant denominations, the Catholic Church and the marginalised African Independent Church. A follow-up publication, Contested Issues in Training Ministers in South Africa (2015) is a critical discussion of eleven contested issues that profoundly shape the possibility of ministerial training. These issues

110 Cf. Thomas Edward Frank, Leadership and Administration. An Emerging Field in Practical Theology, in: IJPT 10/1, 2006, 113-136, 129.

111 Dreyer states that there are many descriptive articles that are published in the Journal of Practical Theology but few are written based on actual empirical evidence, see Dreyer, Recent Developments (n. 107), 8.

112 Cf. James R. Cochrane / John De Gruchy / Robin Petersen, In Word and Deed. Towards a Practical Theology for Social Transformation, Pietermaritzburg (Cluster) 1991; Stephan Bevans, Models of Contextual Theology. Faith and Cultures, New York (Orbis) 2005.

113 Cf. Dale P. Andrews, Practical Theology for Black Churches. Bridging Black Theology and African American Folk Religion, London (Westminster John Knox) 2002.

114 Cf. Naidoo, An Empirical Study (n. 74).

115 Cf. Naidoo, Transformative Remedies (n. 78). 
attend to concerns related to processors, structures, knowledge and practices within theological education in South Africa. The work Men in the pulpit, women in the pew? Addressing gender equality in Africa (2012) is a blend of culture, theology and education viewed through a gendered lens and takes into account the fullness of the African experience. The majestic Handbook of Theological Education in Africa (2013) is a collection of 113 chapters (1100 pages), by ecumenical and evangelical theologians on the continent (with 20 contributions from South Africa), documenting in one location the range of initiatives in theological education. Included are contributions from the four geographic regional networks linked to the World Council of Churches. Many chapters cite Western publications, a symptom of the paucity of available printed or published materials on African theological education. Hence there is need for contextual theological literature, textbooks and electronic resources. The sheer multiplicity of languages and cultures in the region makes church life and education a challenge. Culturally and linguistically appropriate programmes and resources for theological education are urgently needed. The University of South Africa has responded to the call for "vernacular" theologising on the continent and has begun the multilingual Theological Dictionary Project which will translate key theological terms in major South African languages. ${ }^{116}$ Another innovative project worth mentioning is the formation of a professional body for non-formal training called the Association of Ministry Training Practitioners (AMTP). ${ }^{117}$ This was formed out of the need to diversify theological education. With the declining pool of candidates for ordained ministry in the main-line traditions, there has been an increase in training programmes to equip laity for positions of leadership and service. Within the national regulatory framework there is now opportunity for lay ministry training institutions to train and regulate standards for Christian ministry.

In general, there is a need to create a greater awareness of the rich heritage of African theology, of the problems facing Christians on the continent and of the creative approaches adopted by African churches in addressing those problems. There is a need to explore ways and means of reviving sub-regional and regional associations of theological education to create a forum on the African continent. Joint research projects should be set up together with black scholars, in South Africa, in neighbouring countries and all over Africa to establish a new tradition

116 Cf. Johannes Kritzinger / Leomile Mangoedi / D.W. Methula, Towards intercultural theological education in South Africa, Paper delivered at the Association of Theological Institution of Southern Africa, 10 July 2013,1-21, 2f.

117 Cf. Johannes P. van der Walt, Diversification in Training Models. A Key to Overcome Challenges in Ministry Training, in: Marilyn Naidoo (ed.), Contested Issues in Training Ministers in South Africa, Stellenbosch (Sun Media) 2015, 160-172. 
of Africa-directed theological scholarship. Currently research centres include the Network for African Congregational Theology at the University of Stellenbosch that prepares leaders for missional congregations in Southern Africa, the Ujamaa Centre at the University of Kwa-Zulu Natal that focuses on practice of praxis in theological education and the Centre for Contextual Ministry at the University of Pretoria for pastoral skills development.

\section{Conclusion}

Theological training is well-positioned to play key roles in shaping patterns of belief and inquiry while also undertaking its special responsibility to educate and form ministers to serve church and society. The above discussion has attempted to map the South African scene in terms of ministerial formation with its contextual challenges.

The task of transforming ministerial formation is an ongoing and dynamic one. Ideally, a model for ministerial formation is one that has an integrated and ecclesial approach, focused on the theological institution as an educational community led by faithful and exemplary teachers who retain a focus on habitus as a theological method for formation. To do this, ministerial formation needs to become more intentional within the curriculum and influence the content, method and outcomes of theological education. However, context is crucially important as it influences the way we theologize. The challenge remains for us to form our own meanings of sustainable theological education for our own time and place. As Maluleke ${ }^{118}$ has suggested, we need to drink from our own wells. It is a way to assert our identity in Africa, as location and positionality makes a difference.

118 Tinyiko Maluleke, Black and African theologies in the new world order. A time to drink from our own wells, Journal of Theology for Southern Africa 96, 1996, 3-19, $4 \mathrm{f}$. 
Copyright of International Journal of Practical Theology is the property of De Gruyter and its content may not be copied or emailed to multiple sites or posted to a listserv without the copyright holder's express written permission. However, users may print, download, or email articles for individual use. 